\title{
Waterborne outbreaks in the Nordic countries, 1998 to 2012
}

B Guzman-Herrador (BernardoRafael.Guzman.Herrador@fhi.no) ${ }^{1}$, A Carlander ${ }^{2}$, S Ethelberg ${ }^{3}$, B Freiesleben de Blasio $0^{1,4}$,

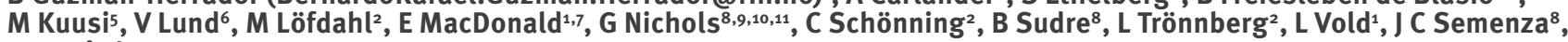
K Nygård

1. Department of Infectious Disease Epidemiology, Norwegian Institute of Public Health, Oslo, Norway

2. Department of Monitoring and Evaluation, Public Health Agency of Sweden, Solna, Sweden

3. Department of Epidemiology Research, Statens Serum Institut, Copenhagen, Denmark

4. Department of Biostatistics, Institute of Basic Medical Sciences, University of Oslo, Oslo, Norway

5. Department of Infectious Disease Surveillance and Control, National Institute for Health and Welfare, Helsinki, Finland

6. Department of Food, Water and Cosmetics, Norwegian Institute of Public Health, Oslo, Norway

7. European Programme for Intervention Epidemiology Training (EPIET), European Centre for Disease Prevention and Control, Stockholm, Sweden

8. European Centre for Disease Prevention and Control, Stockholm, Sweden

9. Gastrointestinal, Emerging and Zoonotic Diseases Department, Public Health England, London, United Kingdom

10. Norwich Medical School, University of East Anglia, Norwich, United Kingdom

11. Department of Hygiene and Epidemiology, University of Thessaly, Thessaly, Greece

Citation style for this article:

Guzman-Herrador B, Carlander A, Ethelberg S, Freiesleben de Blasio B, Kuusi M, Lund V, Löfdahl M, MacDonald E, Nichols G, Schönning C, Sudre B, Trönnberg L, Vold L, Semenza JC, Nygård K. Waterborne outbreaks in the Nordic countries, 1998 to 2012. Euro Surveill. 2015;20(24):pii=21160. Available online: http://www. eurosurveillance.org/ViewArticle.aspx?Articleld=21160

Article submitted on 24 July 2014 / published on 18 June 2015

A total of 175 waterborne outbreaks affecting 85,995 individuals were notified to the national outbreak surveillance systems in Denmark, Finland and Norway from 1998 to 2012, and in Sweden from 1998 to 2011. Between 4 and 18 outbreaks were reported each year during this period. Outbreaks occurred throughout the countries in all seasons, but were most common ( $\mathrm{n}=$ $75 / 169,44 \%$ ) between June and August. Viruses belonging to the Caliciviridae family and Campylobacter were the pathogens most frequently involved, comprising $n=51(41 \%)$ and $n=36(29 \%)$ of all 123 outbreaks with known aetiology respectively. Although only a few outbreaks were caused by parasites (Giardia and/ or Cryptosporidium), they accounted for the largest outbreaks reported during the study period, affecting up to 53,000 persons. Most outbreaks, 124 (76\%) of those with a known water source $(n=163)$ were linked to groundwater. A large proportion of the outbreaks ( $n=130 / 170,76 \%$ ) affected a small number of people (less than 100 per outbreak) and were linked to single-household water supplies. However, in 11 (6\%) of the outbreaks, more than 1,000 people became ill. Although outbreaks of this size are rare, they highlight the need for increased awareness, particularly of parasites, correct water treatment regimens, and vigilant management and maintenance of the water supply and distribution systems.

\section{Background}

outbreaks remain an important public health concern, despite advances in water management and sanitation, even in industrialised countries, as large numbers of people can be infected within a short time period and some of the infections can be life threatening. While people depend on water to live, the supplies can remain vulnerable to contamination from animal and human faeces and provide an excellent environment for the survival and transmission of a range of infectious agents. The traditional paradigms of treatment have been challenged by emerging microorganisms, such as Cryptosporidium, which are resistant to chlorination at the concentrations used in drinking water treatment and require either advanced filtration or ultraviolet (UV) disinfection [1]. In addition, globalisation is changing the distribution of microorganisms [2]. High population density can generate stress on available water sources and sanitation systems.

Drinking water in the Nordic countries is mostly supplied by waterworks (either municipal or managed by private companies). In addition, there are also a considerable number of people who are supplied with water from single-household wells, mainly those living in remote rural areas or in summer houses or cabins in the countryside (Table 1). The water source for drinking water differs among the countries. In Denmark, all drinking water is obtained from groundwater, while in Norway surface water is the main source. In Sweden and Finland, surface water predominates as the source for large waterworks, while groundwater is the main source for medium- and small-sized waterworks (Table 1). Chlorination and UV radiation are the most frequently used disinfection methods for treating surface water (Table 1). Groundwater is usually not disinfected in the Nordic region. Drinking water regulations in all 
TABLE 1

Drinking water: overview of water sources, waterworks, water treatment, Denmark, Finland, Norway and Sweden ${ }^{\mathrm{a}}$

\begin{tabular}{|c|c|c|c|c|}
\hline Variable & Denmark & Finland & Norway & Sweden \\
\hline Water sources & $\begin{array}{c}\text { Almost exclusively } \\
\text { groundwater } \\
(>99 \%) .\end{array}$ & $\begin{array}{c}\text { Large waterworks: } \\
\text { - surface water } 44 \% \\
\text { - groundwater } 41 \% \\
\text { - artificial groundwater } 15 \% \text {. } \\
\text { Medium-sized waterworks: } \\
\text { - groundwater } 92-95 \% \\
\text { - surface water } 5 \% \text {. }\end{array}$ & $\begin{array}{l}\text { Surface water supplies } 61 \% \text { of } \\
\text { the waterworks and } 90 \% \text { of the } \\
\text { served population. } \\
\text { Groundwater supplies } 39 \% \text { of } \\
\text { the waterworks and } 10 \% \text { of the } \\
\text { served population. }\end{array}$ & $\begin{array}{c}\text { Surface water supplies } 10 \% \text { of } \\
\text { the waterworks and } 53 \% \text { of the } \\
\text { population. } \\
\text { Groundwater supplies } 85 \% \text { of } \\
\text { the waterworks and } 23 \% \text { of the } \\
\text { population. } \\
\text { Artificial groundwater supplies } 24 \% \\
\text { of the population and } 5 \% \text { of the } \\
\text { waterworks. }\end{array}$ \\
\hline Waterworks & $\begin{array}{l}2,600 \text { waterworks } \\
\text { serving }>98 \% \text { of } \\
\text { the population; } \\
\text { about } 2 \% \text { are } \\
\text { served by small } \\
\text { private facilities } \\
\text { (such as private } \\
\text { wells). } \\
\text { 2/3 of population } \\
\text { served by <10o } \\
\text { major waterworks. }\end{array}$ & $\begin{array}{l}156 \text { large waterworks supply } \\
4.32 \text { million people. } \\
\text { >700 medium-sized } \\
\text { waterworks provide water } \\
\text { to }>500,000 \text { people. }\end{array}$ & $\begin{array}{c}\text { 1,594 waterworks serving } 4.34 \\
\text { million people, } 88 \% \text { of the } \\
\text { population: } \\
-63 \% \text { are municipal } \\
-2 \% \text { are intermunicipal } \\
-35 \% \text { are private. } \\
\text { These waterworks serve } 71 \% \text {, } \\
24 \% \text { and } 5 \% \text { of the population } \\
\text { supplied by waterworks, } \\
\text { respectively. }\end{array}$ & $\begin{array}{c}1,750 \text { waterworks supply } 84 \% \text { of the } \\
\text { population. } \\
\text { About } 1,000,000 \text { people are } \\
\text { supplied by private wells in } \\
\text { permanent households and about } \\
1,000,000 \text { by private wells in } \\
\text { summer houses }\end{array}$ \\
\hline $\begin{array}{l}\text { Water } \\
\text { treatment }\end{array}$ & $\begin{array}{l}\text { Generally no } \\
\text { disinfection for } \\
\text { aeration and } \\
\text { filtering. }\end{array}$ & $\begin{array}{c}\text { Surface water: mainly } \\
\text { chlorination and UV radiation. } \\
\text { Groundwater: often no } \\
\text { disinfection. }\end{array}$ & $\begin{array}{l}\text { Mainly UV radiation ( } 72 \% \text { of } \\
\text { the served population) and to a } \\
\text { lesser extent chlorination ( } 66 \% \\
\text { of the served population). } 45 \% \\
\text { of the supplied population is } \\
\text { served by waterworks using } \\
\text { coagulation in addition to } \\
\text { disinfection. } \\
\text { About } 7,000 \text { people are served } \\
\text { by waterworks with surface } \\
\text { water without disinfection. }\end{array}$ & $\begin{array}{c}\text { Mainly UV radiation and } \\
\text { chlorination. } 90 \% \text { of the population } \\
\text { connected to surface water supplies } \\
\text { has coagulation in addition to } \\
\text { disinfection. Sometimes in } \\
\text { combination with ozonation and } \\
\text { membrane filtration. } \\
\text { About } 400,000 \text { people are served } \\
\text { by groundwater waterworks without } \\
\text { disinfection. }\end{array}$ \\
\hline
\end{tabular}

UV: ultraviolet.

a The table shows data from 2010 in Norway, 2012 in Denmark and Finland, and 2014 in Sweden.

four countries [3-7] follow the European Union Drinking Water Directive [8].

Municipal health, environmental and food safety authorities are responsible for outbreak detection, investigation and control. Medical practitioners who suspect an outbreak are obliged by law to report it to the municipal authorities. National public health institutes have a consulting role, providing assistance if needed, or a coordination role, if the outbreak affects more than one administrative region [9-12]. All four countries have national surveillance reporting systems in place that municipal authorities should use to notify waterborne outbreaks. All the systems are currently web-based.

In this study, we present information available on waterborne outbreaks notified between 1998 and 2012 in these countries to gain a better understanding of their scope and characteristics in the Nordic region.

\section{Methods}

We analysed data on all waterborne outbreaks notified between 1998 and 2012 (in Sweden, up to 2011) to the national outbreak surveillance systems in each of the four countries. Where data about the outbreaks were incomplete, local and regional authorities responsible for each outbreak investigation provided additional data to make the datasets as complete as possible.

In order to collect and systematise the data, a link to a web-based questionnaire designed using the Questback application [13] was sent to all four countries. The questionnaire included questions on number of cases, date of onset of symptoms of the first case, municipality of occurrence, microorganism(s) involved, water source (surface water, groundwater, other), type of water supply, (including municipal or private waterworks, single household, other), number of people supplied with a given water supply, water disinfection status, factors contributing to the outbreak (pollution of water source, failure of water treatment, failure of 
TABLE 2

Overview of waterborne outbreaks, Denmark, Finland, Norway and Sweden, 1998-2012 (n = 175)

\begin{tabular}{|l|c|c|c|c|}
\hline Country & Number of outbreaks & Outbreaks per year & Number of people involved & Total population in 2012 \\
\hline Denmark & 4 & 0.27 & 660 & 5,426 million [27] \\
\hline Finland & 59 & 3.9 & 22,594 & 5,421 million [28] \\
\hline Norway & 53 & 3.5 & 10,483 & 5,033 million [29] \\
\hline Sweden & 59 & 4.2 & 52,258 & 9,555 million [30] \\
\hline
\end{tabular}

a For Sweden, 1998 to 2011.

water distribution system, other) and level of evidence of drinking water being the cause of the outbreak (strongly associated, probably associated and possibly associated, using the categories developed by Tillett et al. [14]).

Once the data were gathered through the Questback application, we carried out a descriptive analysis of the information.

\section{Results}

\section{Outbreaks}

A total of 175 waterborne outbreaks affecting 85,995 individuals were notified in the four Nordic countries during the study period (Table 2). Outbreaks occurred throughout the four seasons, but were mainly during June to August (75/169 outbreaks, 44\%) and March to May (38/169 outbreaks, 22\%) (Figure 1).

For six outbreaks, the season was not reported. The number of notified outbreaks varied from 4 to 18 outbreaks per year, affecting between 300 and 28,000 persons per year. Most of the outbreaks with known number of cases (130/170 outbreaks, 76\%) had fewer than 100 persons involved. However, all countries except Denmark reported outbreaks with more than 1,000 persons per outbreak (11/170 outbreaks, 6\%), including two outbreaks in Sweden in 2010 and 2011 with more than 20,000 persons involved each time (three-year period trends are shown in Figure 2).

\section{Implicated microorganisms}

The aetiology was known for 123 outbreaks (70\% of all outbreaks). The microorganisms most frequently implicated were viruses belonging to the Caliciviridae family, involved in 51 outbreaks ( $41 \%$ of outbreaks with known aetiology). Of these, norovirus was the cause in 44 outbreaks while in seven outbreaks the specific type of calicivirus was not specified. The second most common microorganism involved was Campylobacter, which caused 36 outbreaks (29\%). The 36 outbreaks involving other laboratory-confirmed microorganisms were caused by pathogenic Escherichia coli (8 outbreaks), Francisella tularensis (6 outbreaks), Salmonella (2 outbreaks) and Shigella and rotavirus (1 outbreak each), and parasites such as Giardia (5 outbreaks) and Cryptosporidium (4 outbreaks). There were nine outbreaks in which more than one microorganism was identified in samples from patients and/or water (Table 3).

In terms of number of outbreak cases reported, the following four groups of pathogens dominated as aetiological agent and contributed to more than $90 \%$ of all cases: Cryptosporidium (58\%), viruses belonging to the Caliciviridae family (17\%), Campylobacter (9\%) and Giardia (7\%) (Table 3).

Certain types of microorganisms were country-specific, such us $F$. tularensis, which was only notified in Norway, in six outbreaks.

Type of water supply, water source, disinfection status and contributing factors

Most of the outbreaks with known water supply were associated with waterworks (101/168 outbreaks, $60 \%)$. Of these, 62 were municipal waterworks and 39 were owned by private companies. Around $35 \%$ of outbreaks $(58 / 168)$ occurred in single households. In addition, nine involved an outdoor open water source. Groundwater was the water source involved in most of the outbreaks with known water source (124/163 outbreaks, $76 \%$ of those with known water source) followed by surface water in 39 outbreaks (24\%). The distribution of type of water supply and water source involved in outbreaks remained relatively stable during the study period (Figure 2). Outbreaks involving municipal waterworks with surface water as water source (17/175 outbreaks) accounted for the largest number of cases $(67 \%$ of all cases $(57,315 / 85,995))$, followed by outbreaks involving municipal waterworks with groundwater as water source (42/175 outbreaks) with 23,816 cases ( $28 \%$ of all cases).

In 122 outbreaks, water had not been disinfected before the outbreak. All outbreaks that occurred in single households in which disinfection status was known (50 outbreaks) were caused by non-disinfected water. The most common contributing factor was contamination at the source (95 outbreaks). Failures in the distribution system accounted for 26 outbreaks (Table 4 ).

Level of association of outbreak with water According to the classification developed by Tillett et al. [14], 32 outbreaks were classified as being 'strongly' 


\section{FIGURE 1}

Seasonal distribution of waterborne outbreaks by size of outbreak, Denmark, Finland, Norway and Sweden, 1998-2012a $(\mathrm{n}=169)$
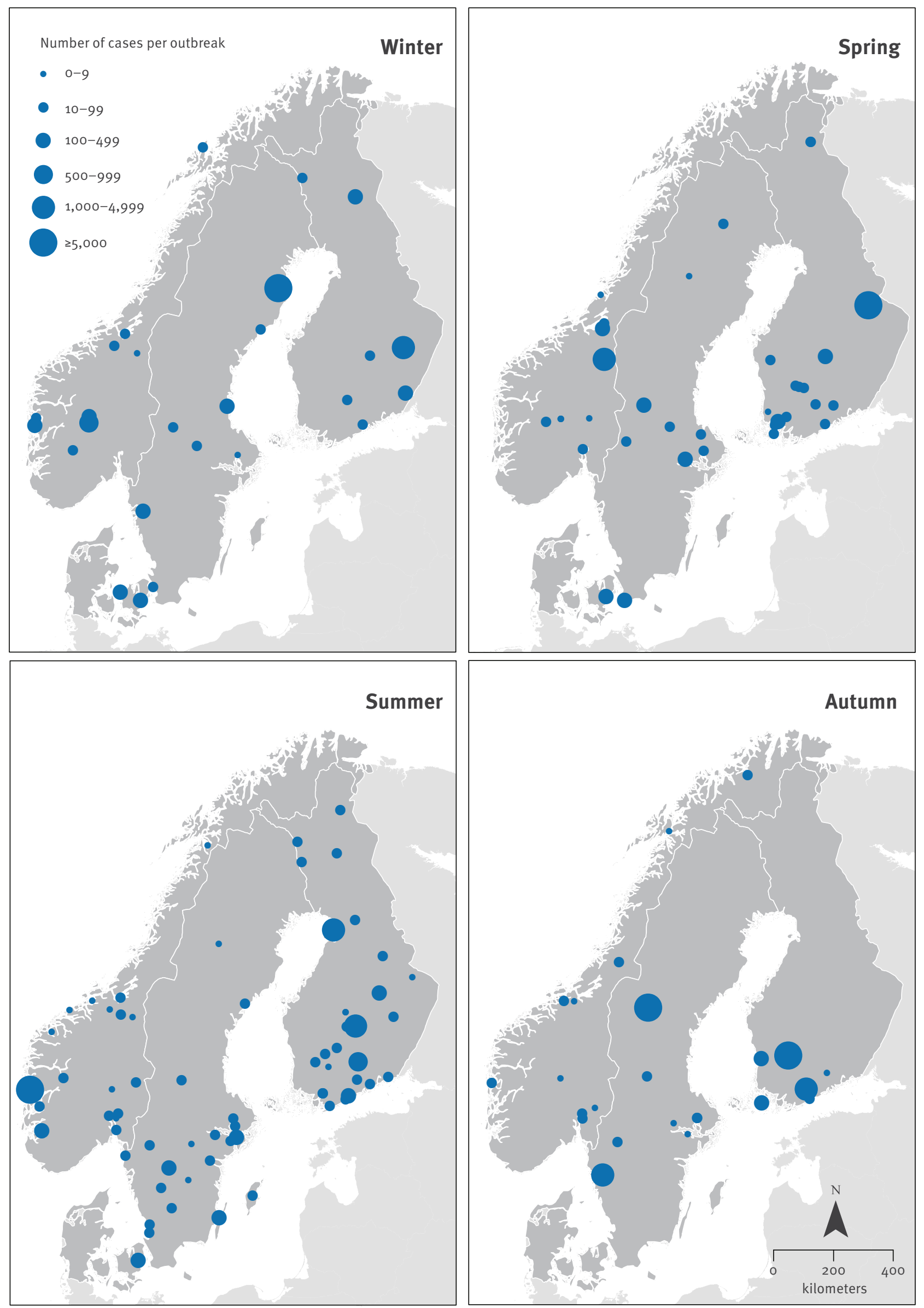

a For Sweden, 1998 to 2011. 


\section{FIGURE 2}

Waterborne outbreaks by three-year periods and (A) type of water supply and water source $(\mathrm{n}=175)$ and $(\mathrm{B})$ size of outbreak, Denmark, Finland, Norway and Sweden, 1998-2012 $(\mathrm{n}=170)$

\section{A Type of water supply and water source}

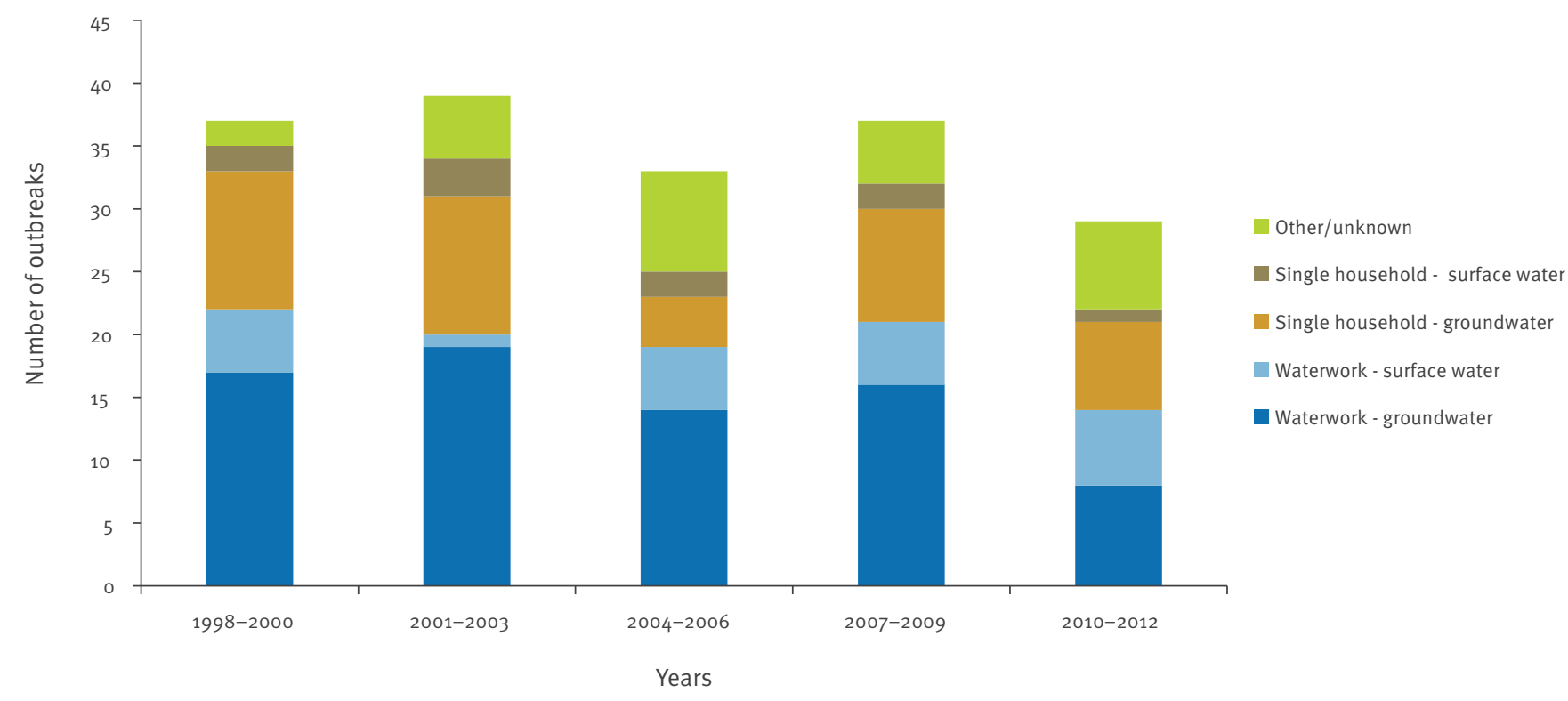

B Size of outbreak

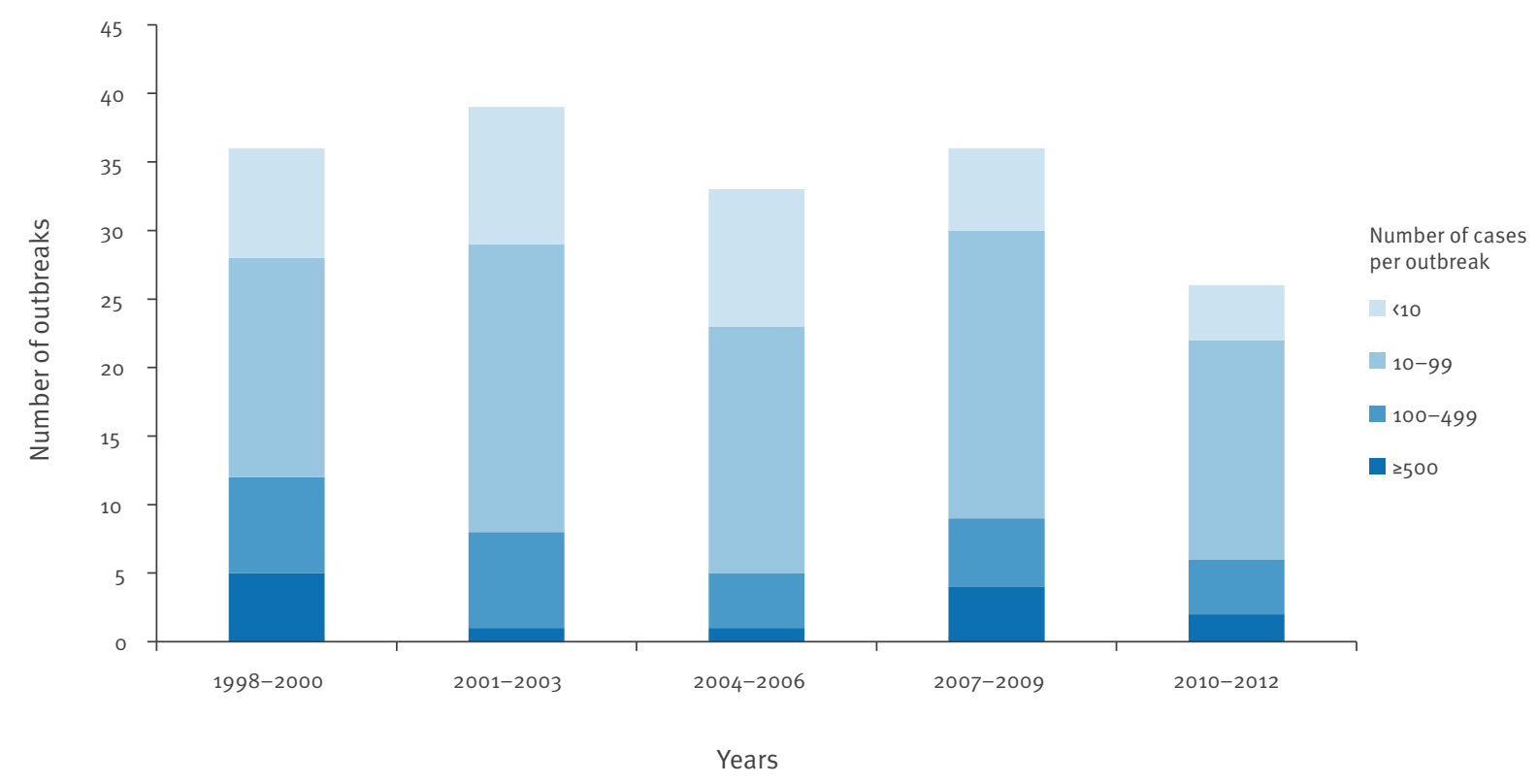

a For Sweden, 1998 to 2011.

associated with water, 51 were classified as 'probably' associated and 56 as 'possibly' associated with water (Figure 3). The proportion of outbreaks with a known level of association was higher as the number of cases involved increased. A total of 36 outbreaks could not be classified due to missing information.

\section{Discussion}

In the 15-year period included in this study, a total of 175 waterborne outbreaks affecting thousands of people were notified in the Nordic countries. However, we consider the numbers presented to be an underestimation of the true occurrence. For example, outbreaks linked to municipal or inter-municipal waterworks are more likely to be recognised and reported than those 
Factors contributing to waterborne outbreaks by type of water supply, Denmark, Finland, Norway and Sweden, 1998-2012 $(\mathrm{n}=175)$

\begin{tabular}{|c|c|c|c|c|c|c|c|}
\hline \multirow{3}{*}{ Contributing factors } & \multicolumn{6}{|c|}{ Number of outbreaks (number of patients involved) by type of water supply } & \multirow{3}{*}{ Total } \\
\hline & \multirow{2}{*}{$\begin{array}{c}\text { Single } \\
\text { households }\end{array}$} & \multicolumn{2}{|c|}{ Municipal waterworks } & \multicolumn{2}{|c|}{ Private waterworks } & \multirow{2}{*}{$\begin{array}{c}\text { Other/ } \\
\text { unknown }\end{array}$} & \\
\hline & & Groundwater & Surface water & Groundwater & Surface water & & \\
\hline $\begin{array}{l}\text { Contamination at } \\
\text { source }\end{array}$ & 29 (579) & $15(11,410)^{\mathrm{b}, \mathrm{c}}$ & $6(55,005)^{b}$ & $19(934)^{b}$ & $1(15)$ & $12(455)$ & $\begin{array}{c}82 \\
(68,398) \\
\end{array}$ \\
\hline $\begin{array}{l}\text { Failures in the } \\
\text { distribution system }\end{array}$ & - & $11(7,594)$ & $3(238)$ & - & - & $2(24)$ & $16(7,856)$ \\
\hline $\begin{array}{l}\text { Failures in water } \\
\text { treatment }\end{array}$ & - & - & $1(4)$ & 1 (unknown) ${ }^{b}$ & - & - & $2(4)$ \\
\hline $\begin{array}{l}\text { Contamination } \\
\text { of the water } \\
\text { source plus failures } \\
\text { in water treatment }\end{array}$ & $2(55)$ & - & $1(1,700)$ & - & - & - & $3(1,755)$ \\
\hline $\begin{array}{l}\text { Contamination } \\
\text { of the water } \\
\text { source plus failures } \\
\text { in the distribution } \\
\text { system }\end{array}$ & $1(16)$ & $3(2,549)$ & - & $3(117)$ & $1(100)$ & $1(360)$ & $9(3,142)$ \\
\hline $\begin{array}{l}\text { Contamination } \\
\text { of the water } \\
\text { source plus failures } \\
\text { in the distribution } \\
\text { system plus failures } \\
\text { in water treatment }\end{array}$ & - & $1(35)$ & - & - & - & - & $1(35)$ \\
\hline Unknown & $26(471)$ & $12(2,228)$ & $6(368)$ & $9(1,149)$ & $3(71)$ & $6(518)$ & $62(4,805)$ \\
\hline Total & $58(1,121)$ & $42(23,816)$ & $17(57,315)^{d}$ & $32(2,200)$ & $5(186)$ & $21(1,357)$ & $\begin{array}{c}175 \\
(85,995)\end{array}$ \\
\hline
\end{tabular}

Dashes indicate that there were no such outbreaks.

a For Sweden, 1998 to 2011.

b There was an outbreak with an unknown number of people involved. There were five such outbreaks in total.

There were two outbreaks in this category with unknown numbers of people.

d Two outbreaks accounted for $54.7 \%(47,000)$ of all cases.

that involve a single-household water supply. Similarly, outbreaks caused by treatment failure or contamination of source water affecting all the persons supplied in the area are more likely to be recognised than outbreaks caused by failures in the water distribution system that affect only a small part of the population. Outbreaks of diseases with severe symptoms are also more likely to be identified as people are more likely to seek medical attention. Additionally, it is difficult to state whether the geographical differences in reported outbreaks reflect a real difference in risk between the regions or just differences in outbreak detection and reporting routines by the local authorities.

Viruses belonging to the Caliciviridae family, mainly noroviruses, and Campylobacter were the groups of microorganisms most frequently associated with waterborne outbreaks. The largest outbreak notified in Denmark of campylobacteriosis, affecting more than 200 people in the city of Køge in 2010 [15]. It was caused by a point source contamination, most probably in the central water supply system. One of the largest waterborne outbreaks reported in Norway, in the city of Røros in 2007 with 1,500 sick, was also caused by Campylobacter [16]. Several events that might have caused a fall in water pressure and influx of contaminated water into the water distribution system were identified as the main contributing factor to the outbreak in the environmental investigation. In addition, it was considered that faecal contamination from birds, containing Campylobacter, could have passed directly to a production well of groundwater from an uncovered extra service well (Arnulf Moseng, Røros municipality, personal communication, November 2010).

Outbreaks caused by parasites (Giardia and/or Cryptosporidium) were few but large in size. The largest outbreaks reported in Sweden and Norway were caused by these types of microorganisms. In Norway, a giardiasis outbreak occurred in 2004 in the city of Bergen, resulting in an estimated 6,000 cases. In this outbreak, leaking sewage pipes combined with insufficient water treatment for inactivation of parasites (only chlorination was used) in the water supply serving 


\section{FIGURE 3}

Waterborne outbreaks by level of association with water ${ }^{\mathrm{a}}$ by size of outbreak, Denmark, Finland, Norway and Sweden, 1998-2012 ${ }^{\mathrm{b}}(\mathrm{n}=170)^{\mathrm{c}}$

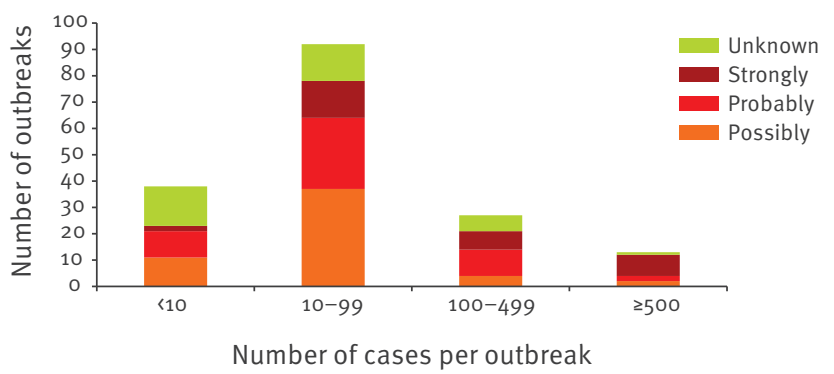

a Known for 139 outbreaks.

b For Sweden, 1998 to 2011.

Five outbreaks with an unknown number of cases.

the city centre was the likely cause [17]. In Sweden, a cryptosporidiosis outbreak at the end of 2010 in the city of Östersund that involved around 27,000 persons is the largest waterborne outbreak ever reported in Europe $[18,19]$. One suspected source was sewage water from a few households being discharged directly into a stream, which ran into a lake from which the drinking water was obtained. The second largest outbreak in Sweden was also caused by Cryptosporidium and occurred half a year later in Skellefteå, further north, affecting around 20,000 persons. The cause of the outbreak was unknown but it was considered to be partly related to the Östersund outbreak. The surface waterworks in both cities lacked sufficient barriers for parasites. The outbreaks resulted in increased awareness regarding barriers and risks for waterborne disease, and actions have been taken by national authorities and at municipal waterworks. The ability to detect Cryptosporidium and Giardia in primary diagnostic laboratories has also been identified as critical for being able to detect and respond to outbreaks. The occurrence of large outbreaks should stimulate health professionals to encourage routine detection of these pathogens in samples from patients with diarrhoea. The detection of only one Cryptosporidium outbreak before 2010 suggests it is likely that other outbreaks may have been missed.

Nine outbreaks involved multiple microorganisms. These types of outbreaks were mainly caused by contamination with sewage. In Finland, the largest outbreak reported occurred in 2007 in the city of Nokia, where C. jejuni, norovirus, Giardia and Salmonella were detected in drinking water [20]. Cross-connection between the waste water system and drinking water pipeline contaminated the drinking water distribution network.

In 52 outbreaks, $30 \%$ of the total, the microorganism involved was not identified. This could be related to problems associated with microbiological testing in outbreak settings. Microbiological analysis of water during an outbreak is challenging as the contamination is often of short duration, and by the time the outbreak is detected, the contamination episode is over. Technically, it is easier to find the relevant pathogen in patient stool samples than in water samples. However, few people with uncomplicated diarrhoea consult a clinician, and stool samples are not always requested. Epidemiological analysis of outbreaks requires sufficient case numbers to give statistically significant results. This reinforces the importance of encouraging patients to go to a doctor in order to get a stool sample taken during outbreak investigations.

A large proportion of outbreaks, although of small size, occurred in single households. This highlights the importance of correct protection of wells. If this cannot be achieved, disinfection of wells should be considered. The largest outbreaks were those in which drinking water was obtained from municipal waterworks supplied by surface water, followed by those involving municipal waterworks supplied by groundwater. It is important that the function of barriers in waterworks with surface water as their water source is evaluated and if necessary improved or supplemented by additional treatment steps. Water utilities also need to be encouraged to better protect groundwater sources to minimise the risk of contamination.

In a previous report on waterborne outbreaks in the Nordic countries, based on 17 years' data (1975 to 1992), a total of 143 outbreaks were recorded [21], lower than the total number reported in our study. This could be explained by the fact that surveillance systems in the Nordic countries have been further improved and developed during the last decades, including new and improved web-based outbreak notification systems [22]. In the previous report, the proportion of outbreaks in which groundwater and surface water were involved was similar, while in our study, groundwater was the source most commonly involved. In the previous report, Denmark was also the country with fewest outbreaks reported. Campylobacter and Caliciviridae viruses were the most frequent microorganisms reported in the previous study. The proportion of outbreaks with unknown microorganisms in our study was much lower $30 \%$ compared with around $60 \%$ in the previous report), likely due to improvements in methods and routines for microbiological analysis.

The aetiologies of waterborne outbreaks reported by other European countries differ from those of the outbreaks presented here. During a 10-year period (1992 to 2003$), 69 \%$ of all waterborne outbreaks reported in Wales and England were caused by Cryptosporidium [23]. In the United States (1971-2006) and Canada (1974-2001), the most frequently reported microorganisms in outbreaks associated with drinking water were parasites, of which Giardia was the most common $[24,25]$. While noroviruses were the most frequently reported viruses in the United States, 
Campylobacter was only the third most frequent bacteria associated with waterborne outbreaks, after Shigella and Salmonella, which are not very common waterborne pathogens in the Nordic countries. In Canada, Campylobacter was the most common bacteria reported. The reasons for the differences in the aetiologies of the outbreaks in these countries are not completely understood. It might be due to varying levels of endemicity of the diseases or different routines in sampling, laboratory procedures or reporting.

In only a few of the outbreaks included in our study was drinking water strongly associated with the outbreak. Denmark and Finland were the countries with the highest proportion of outbreaks with a strong association. In most of the notified outbreaks, water quality failure, water treatment problem or descriptive epidemiology suggested that water was involved. In only a few of the outbreaks was a pathogen identified in the water or an analytical epidemiological study confirmed an association with water: both are always needed for an outbreak to be classified as strongly associated with drinking water according the Tillett et al. criteria [14]. The lack of demonstrated association in an outbreak partly reflects the difficulties and limitations that investigators face when performing epidemiological, microbiological and environmental investigations in these settings. Most of the outbreaks reported were small and had few laboratory-diagnosed cases. It should be emphasised that in outbreak situations every effort needs to be made to confirm cases by laboratory identification and typing of isolates so that appropriate analytical epidemiological investigations can be undertaken.

Outbreaks of disease caused by contaminated drinking water still occur every year in the Nordic region, pointing to several emerging and persisting public health challenges associated with drinking water systems. Thus it is important to adopt the World Health Organization approach to water supply described in Water Safety Plans [26]. Although large outbreaks due to contaminated water are rare, they highlight the need for increased awareness in the public health sector, particularly of Cryptosporidium, correct treatment regimens (using coagulation, filtration and disinfection) and vigilant management and maintenance of water supply and distribution systems.

\section{Acknowledgments}

This study has been performed as part of the ECDC commissioned project 'Waterborne outbreaks and climate change' (0)/06/02/2012-PROC/2012/011). We would like to thank all municipal health, environmental and food safety authorities in Denmark, Finland, Norway and Sweden that have conducted every single outbreak investigation that is included in this study.

Conflict of interest

None declared.
Authors' contributions

$\mathrm{BGH}$ was the main investigator in the study and drafted the manuscript. KN provided supervision and scientific coordination throughout the study. All authors provided scientific input. All authors participated in manuscript writing and revision. All authors read and approved the final manuscript.

\section{References}

1. Funari E, Kistemann T, Herbst S, Rechenburg A. Technical guidance on water-related disease surveillance. Copenhagen: World Health Organization Regional Office for Europe; 2011. Available from: http://www.euro.who.int/__data/assets/pdf_ file/0009/149184/e95620.pdf

2. Globalization and infectious diseases: a review of the linkages. Geneva: World Health Organization; 2004. Available from: http://www.who.int/tdr/publications/documents/seb_topicz. pdf

3. Danish Nature Agency. Vand I hverdagen/Drikkevand. [Water in daily life/Drinking water]. Copenhagen: Danish Nature Agency. [Accessed 15 Jun 2015]. Danish. Available from: http://www. naturstyrelsen.dk/Vandet/Vand-i-hverdagen/Drikkevand/

4. Sosiaali- ja terveysministeriön asetus talousveden laatuvaatimuksista ja valvontatutkimuksista. [Decree of the Ministry of Social Affairs and Health Relating to the Quality and Monitoring of Water Intended for Human Consumption]. Helsinki: Ministry of Social Affairs and Health; 2000. [Accessed 15 Jun 2015]. Finnish. Available from: http://www.finlex.fi/fi/ laki/alkup/2000/20000461

5. Myrstad L, Nordheim CF, Einan B. Vannrapport 116. Rapport fra Vannverksregisteret. Drikkevannsstatus (data 2007 og 2008). [Water report 116. Report from the waterworks registry. Status of Drinking water (data from 2007 and 2008)]. Oslo: Nasjonalt folkehelseinstitutt; 2011. Norwegian. Available from: http:// www.fhi.no/dokumenter/od34aeb796.pdf

6. Forskrift om vannforsyning og drikkevann. [Norwegian drinking water regulations]. Oslo: Ministry of Health and Care Services. [Accessed 15 Jun 2015]. Norwegian. Available from: http:// www.lovdata.no/cgi-wift/ldles?doc=/sf/sf/sf-20011204-1372. html

7. Livsmedelsverkets föreskrifter om dricksvatten, SLVFS 2001:30. [National Food Authority's regulation on drinking water, SLVFS 2001:30]. Sweden: National Food Safety Authority. [Accessed 15 Jun 2015]. Available from: http:// www.livsmedelsverket.se/globalassets/om-oss/lagstiftning/ dricksvatten---naturl-mineralv---kallv/slvfs-2001-30-kons.pdf

8. Council Directive $98 / 83 /$ EC of 3 November 1998 on the quality of water intended for human consumption. Official Journal of the European Union. Luxembourg: Publications Office of the European Union. 5.12.98; L 330. Available from: http://eur-lex. europa.eu/legal-content/EN/TXT/?uri=CELEX:31998Lo083

9. Vejledning i opklaring af fødevare- og vandbårne sygdomsudbrud. [Investigation of food and waterborne disease outbreaks]. Copenhagen: Dansk Zoonosecenter: 2002. Danish. Available from http://www.ssi.dk/ /media/Indhold/ DK\%20-\%20dansk/Smitteberedskab/Overvaagning\%20i\%20 Danmark/opklaring_sygdomsudbrud.ashx

10. Kapperud G, Nygård K. Veiledning i oppklaring av sykdomsutbrudd som skyldes smitte fra næringsmidler eller dyr. [Outbreaks of food-and waterborne diseases - Investigation and response. Oslo: Norwegian Institute of Public Health and Norwegian Food Safety Authority; 2009. Norwegian. Available from: http://www.fhi.no/ dokumenter/1ca929a5a4.pdf

11. Valtioneuvoston asetus elintarvikkeiden ja veden välityksellä leviävien epidemioiden selvittämisestä. [Decree on the investigation of food-and waterborne outbreaks]. Helsinki: Ministry of Social Affairs and Health; 2011. [Accessed 15 Jun 2015]. Finnish. Available from: http://www.finlex.fi/fi/laki/ alkup/2011/20111365

12. Livsmedelsverkets föreskrifter om epidemiologisk utredning av livsmedelsburna utbrott, LIVSFS 2005:7. [National Food Authority's regulation on epidemiological investigations on foodborne outbreaks, LIVSFS 2005:7]. Sweden: National Food Authority; 2005. Swedish. Available from: http://www. livsmedelsverket.se/globalassets/om-oss/lagstiftning/ offentlig-kontroll/livsfs-2005-7-kons.pdf.

13. Questback. [Accessed 15 Jun 2015]. Available from: http:// www.questback.com/

14. Tillett HE, de Louvois J, Wall PG. Surveillance of outbreaks of waterborne infectious disease: categorizing levels of evidence. Epidemiol Infect. 1998;120(1):37-42. http://dx.doi.org/10.1017/ So950268897008431 PMID:9528816 
15. Gubbels SM, Kuhn KG, Larsson JT, Adelhardt M, Engberg J, Ingildsen $\mathrm{P}$, et al. A waterborne outbreak with a single clone of Campylobacter jejuni in the Danish town of Køge in May 2010. Scand J Infect Dis. 2012;44(8):586-94. http://dx.doi.org/10.310 9/00365548.2012.655773 PMID:22385125

16. Jakopanec I, Borgen K, Vold L, Lund H, Forseth T, Hannula R, et al. A large waterborne outbreak of campylobacteriosis in Norway: the need to focus on distribution system safety. BMC Infect Dis. 2008;8(1):128. http://dx.doi.org/10.1186/1471-23348-128 PMID:18816387

17. Nygård K, Schimmer B, Søbstad $\emptyset$, Walde A, Tveit I, Langeland $\mathrm{N}$, et al. A large community outbreak of waterborne giardiasisdelayed detection in a non-endemic urban area. BMC Public Health. 2006;6(1):141. http://dx.doi.org/10.1186/1471-2458-6141 PMID:16725025

18. Smittskyddsinstitutet (SMI). Cryptosporidium i Östersund. [Cryptosporidium in Östersund]. Solna: SMI; 2011. Swedish. Available from: http://www.folkhalsomyndigheten.se/ pagefiles/12853/cryptosporidium-i-ostersund.pdf

19. Widerström M, Schönning C, Lilja M, Lebbad M, Ljung T, Allestam G, et al. Large outbreak of Cryptosporidium hominis infection transmitted through the public water supply, Sweden. Emerg Infect Dis. 2014;20(4):581-9. http://dx.doi.org/10.3201/ eid2004.121415 PMID:24655474

20. Miettinen IT, Lepistö O, Pitkänen T, Kuusi M, Maunula L, Laine J et al. A waterborne outbreak caused by a severe faecal contamination of distribution network: Nokia case. In: Kay D, Fricker C, editors. The significance of faecal indicators in water: a global perspective. London: Royal Society of Chemistry Publishing; 2012. p. 34-7. DOI:10.1039/9781849735421-00034

21. Vattenburna infektioner i Norden. [Waterborne infections in the Nordic countries]. Copenhagen: TemaNord; 1994:585. ISBN 92-912-0511-7. 1994 .

22. Guzman-Herrador B, Vold L, Berg T, Berglund TM, Heier B, Kapperud G, et al. The national web-based outbreak rapid alert system in Norway: eight years of experience, 2006 2013. Epidemiol Infect. 2015;1-10. http://dx.doi.org/10.1017/ So95026881500093X PMID:26028358

23. Smith A, Reacher M, Smerdon W, Adak GK, Nichols G, Chalmers RM. Outbreaks of waterborne infectious intestinal disease in England and Wales, 1992-2003. Epidemiol Infect. 2006;134(6):1141-9. http://dx.doi.org/10.1017/ So950268806006406 PMID:16690002

24. Craun GF, Brunkard JM, Yoder JS, Roberts VA, Carpenter J, Wade $\mathrm{T}$, et al. Causes of outbreaks associated with drinking water in the United States from 1971 to 2006. Clin Microbiol Rev. 2010;23(3):507-28. http://dx.doi.org/10.1128/CMR.00077-09 PMID:20610821

25. Schuster CJ, Ellis AG, Robertson WJ, Charron DF, Aramini JJ, Marshall BJ, et al. Infectious disease outbreaks related to drinking water in Canada, 1974-2001. Can J Public Health. 2005;96(4):254-8. PMID:16625790

26. World Health Organization (WHO). Water safety plans. Managing drinking-water quality from catchment to consumer. Geneva: WHO; 2005. Available from: http://www.who.int/ water_sanitation_health/dwq/wsp0506/en/

27. Statistics Denmark. Copenhagen: Statistics Denmark. [Accessed 15 Jun 2015]. Available from: https://www.dst.dk/en

28. Statistics Finland. Helsinki: Statistics Finland. [Accessed 15 Jun 2015]. Available from: www.stat.fi

29. Statistics Norway. Oslo: Statistics Norway. [Accessed 15 Jun 2015]. Available from: https://www.ssb.no

30. Statistics Sweden. Stockholm: Statistics Sweden. [Accessed 15 Jun 2015]. Available from: http://www.scb.se/ 